\title{
THE ESSENCE AND MANIFESTATIONS OF SOCIETAL DESTRUCTION: SERBIA SINCE THE BEGINNING OF THE NINETIES
}

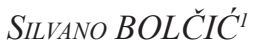

\begin{abstract}
Sociological concepts of social disorganization, disintegration, social involution and social anomie offer relevant explanations of many developments in Serbia in the 1990s. However, if one relies only on such concepts, one will not get a comprehensive understanding of the extremely destructive developments that occurred simultaneous in practically all spheres of society (economy, politics, culture, and spiritual), and the long-lasting negative social developments that occurred even after the regime change in Serbia at the end of 2000. The author presents a more complex sociological concept, the concept of destroyed society, to describe 'things' that happen to society when its basic structure as an ordered social community is being destroyed.

The essential features of societal destruction include a radical, long-lasting disintegration of societal structure, the social system and societal culture, generating the destruction of society's identity and vitality; the 'empting' of key social institutions (institutions of state, of the economy, policy, culture..), when institutions no longer carry out their institutionally-specific activities and degenerate into empty social forms; the prevalence of quasi and para-phenomena, which are outside regular social control and replace normal forms of activities established by institutions; the annulment and making of senseless basic social roles (occupations, professions, even roles in inter-personal relations); de facto making the system of social rules 'out of order', disrespect for the legal regulation of social development, an absence of morality; the life 'behind the (public) scene' becomes the real life of people, so that lies tend to dominate social communications; an accumulation of 'unfinished happenings', of activities which started but did not end, leading to the destruction of a sensible future; mass forgetting of ethics and morality which leads to widespread tolerance of inhuman doings; massive impoverishment, regression to low-level practices, even among members of society who usually would not be faced with poverty.
\end{abstract}

1 Silvano BOLČIĆ is retired professor of sociology at the University of Belgrade, e-mail: sbolcic@yahoo.com 
Specific manifestations of the complete destruction of Serbian society in the 1990s are illustrated in the paper using empirically based findings ${ }^{2}$. Some comments on the possible reconstitution of destroyed Serbian society since the regime change are presented in the last part of the paper.

KEYWORDS destroyed society, destruction of institutions, determinants of societal destruction, reconstitution of society, Serbian society, post-socialist transition

In theoretical works of sociology, one can find references to society such as the following: reviews of historically-known formations of society; descriptions of the main forms of social change; of the stable functioning of society; of evolutionary and revolutionary components of social change; characterizations of social stagnation, involution, and social regression, of social disorganization, social disintegration and of social anomie (when developments in society become unpredictable, uncontrollable, due to the destruction of social values and rules). All these conceptual tools could be of use in understanding social developments in Serbia in the 1990s, for comparing them to developments in other countries, as well as for comparing recent and past events in Serbia as a society.

Specifically, concepts of social disorganization, disintegration, involution and social anomie certainly offer relevant explanations of many developments in Serbia in the 1990s. Still, by relying only on such concepts, one will not gain a comprehensive understanding of the multiplied, quasi-independent, extremely negative and destructive developments in practically all spheres of society (such as the economy, politics, culture, moral and the spiritual sphere, including the interpersonal relations of individual members of Serbian society) in the 1990s. Furthermore, by relying only on the usual meaning of these concepts it seems impossible to understand the key causes of the enduring, long-lasting and disturbing inefficiency of social action that has been prevalent in Serbia since the regime change in the fall of the year 2000; action that was introduced with the intention of rebuilding institutions, reorganizing society, strengthening the role of the state, reestablishing the confidence of the public in the integrative agents of society such as church, school and cultural institutions, restoring faith in the "subjects" of sociosystemic institutions, as well as rebuilding the trust of citizens in those who hold leading positions in society, who are now being chosen according to

2 This paper is based on findings presented in S. Bolčić, Razaranje i rekonstitucija društva: Srbija na prelazu u 21. vek (Destruction and reconstitution of society: Serbia in transition to the $21^{\text {st }}$ century), 2013, Beograd, Službeni glasnik. 
new, democratic electoral procedures and who are under public control. The problem is that all these concepts are related to some partial aspect of social reality, such as the problem with inappropriate regulation of the political sphere, of shortcomings of social organization, of a lack of morality and value confusion in society, with a presumed standpoint that society as such still exists, and that society has just lost its ability to intervene in a systemic way to stop or prevent undesired social development.

Considering all the features of negative social developments in Serbia in the 1990s, the long-lasting destructive consequences of those developments and the persistence of the negative effects of those developments, in spite of a multitude of actions by internal and external social actors aimed at restoring social normalcy in Serbia it seems advisable to analyze these developments by using another, more complex sociological concept; the concept of destroyed society, which has not been used so far in the analysis of societal developments in Serbia in the 1990s, or in the analysis of other highly-disrupted contemporary societies. The current author introduced, for the first time, the concept of destroyed society in a discussion held within the Serbian Sociological Association in the fall of 1990. The concept was further elaborated in a paper published in Prošić -Dvornić, 1994; see also Bolčić, 1994.

It is important to stress that with this concept one describes things that are happening to society, whose basic features as an ordered social community are being destroyed. From the text which follows, one should grasp the heuristic value of this concept in the general analysis of destroyed societies, primarily for studying and understanding social developments in Serbia during the 1990s and afterwards. The author believes that the concept of "destroyed society" proposed here could also prove useful in the study of other "post-Yugoslav" societies, and some other contemporary societies which have faced severe social disruption due to their 'internal' (and other kinds of) wars. It is expected that this concept of destroyed society could be included in sociology's theoretical tools, especially within that part of sociology that deals with processes of social dynamics to pinpoint the case of the disappearance of pre-existing global society.

Both in the lay person's and in the sociologically-educated mind, there is a prevailing perception of society as something that "exists eternally", regardless of specific social developments. Considering events in the distant past, people could possibly assume that some societies may have disappeared due to natural catastrophes, or that some civilizations (like the Roman, Inca and Maya civilizations) could have disappeared or could have be conquered by other civilizations, while the substantive causes of such disappearances of civilizations remain mainly unclear. One should mention that there are 
relevant descriptions (see, for example, Tainter, 1988, Diamond, 2005) of many societies which have vanished from the map of human societies in the past centuries. It has been established in such studies that the fundamental or, at least crucial, causes of the decay of most of these vanished societies lay in their social constitution, particularly, in socio-systemic failures which were not observed and eliminated in time. As long as the decay of those societies resulted from the "wrong doings" of their key social actors, one can claim that these were cases of "destruction of society", and not of the disappearance of society due to a natural catastrophe. Evidently, the "destruction of society" is not an unknown social phenomenon. The "novelty" proposed in this study is in the analytical conceptualization of this phenomenon and in the specific application of this concept to explain social developments during the 1990s and the early 2000s in Serbia, where the signs of "destruction of society" were clearly manifested and have been highlighted in numerous published works on sociology by the current author (see Bolčić, 2013).

The very formation of society is a complex social process, but equally complex are the processes of its destruction, as are the factors in the reconstitution of a society. As with other areas of human life, where it is easier and faster to ruin or destroy things than to fix, improve or rebuild them, it seems that it was easier to enter the process of the "destruction of society" in Serbia in the 1990s than to come out of this stage afterwards. After considering this finding it may be stated that people in Serbia should have shown impatience while requesting that the processes of the "destruction of society" be stopped, but they should be reasonably patient in their expectations for a relatively quick reconstitution of society, and of the rebuilding of Serbia as a modern and successful society.

It should be stressed that the concept of destroyed society is being used here as a concept of ideal-type analysis which has been elaborated in sociology by Max Weber (Weber, M. 1949). Such a concept, while requiring analytical insight into the phenomenological ("historical") reality of society, does not assume full correspondence between this phenomenological reality and the "reality" which is being described by the use of the concept as a "generalized" (abstract) description of a given social reality. The ideal-type concept is a peculiar "mental construct", by which real features of reality are "idealized" and "generalized" with the aim of making the given characteristics of reality more visible and apprehensible in their substance. Therefore the statement that a given "standing of society" is denoted as a "destroyed society" does not imply that all dimensions of society have been fully destroyed, nor that some manifestation of the destruction of society did not exist in the time before the given society fell into "destruction" - or that some manifestations 
of the "destruction of society" were not features of societies which, according to "ideal-type" analysis, could not be denoted as "destroyed societies". Considering some conditionality and the research limits of such an analysis, qualifying a given society as a "destroyed society" cannot be viewed as a subjective (in value terms, "pessimistic") perception of social reality. The scientific validity of such a concept, and of findings based on this concept, should be judged by the "heuristic fertility" of such an analysis, by empirical findings and their reliability, as well as by the practical implications of the findings based on the concept of destroyed society.

\section{ESSENTIAL FEATURES OF A DESTROYED SOCIETY}

From the starting proposition that the "destruction of society" denotes the dominant features of the constitutive aspects of society in its totality, it follows that the features described below are the essential features of "social destruction":

Radical disintegration of social structure, social system and societal culture, disintegration of a longer duration; an absence of visibly new integration by which a given society could regain its identity, its peculiar "social personality" and vitality;

"Emptying" of the key social institutions (state institutions, economic, regulative, cultural institutions and institutions of socialization), "emptying" of institutions of their institutionally specific activities, transformation of institutions into "empty social forms", where there are no happenings that are substantively important to the everyday lives of people in the given society;

Annulment of and creation of senseless basic social roles such as occupational roles, professions, social functions, even roles in inter-personal relations such as the roles of parents, relatives, friends, etc.;

De facto putting the system of social rules "out of order", and, in particular, disrespect for the legal regulation of social development, generalized disregard for legal rules, but also, "the forgetting of morality" in interpersonal relations, leading altogether to a situation whereby normative social order becomes, in practice, irrelevant to the everyday lives of people in a given society;

Living life "behind the scenes" becomes normal practice for people (every member of society, both the most powerful and "ordinary" citizens, are compelled to hide, to cover up things they are doing); public life becomes, in fact, a "facade", even a "masquerade", preventing others from seeing what should not be known and seen, so that lies tend to dominate social communications; 
An accumulation of "unfinished happenings", of activities (in the societal domain, as well as in the domain of individual doings) which started but did not end; the consequence being the elimination of perspective, the destruction of a sensible relationship with the future (people have no sensible answer to the question: What should I do today or tomorrow?);

Prevalence of "quasi" and "para-phenomena" instead of normal forms of activity that are established by institutions (quasi, or para-institutions, paraorganizations, etc.), which are outside regular social control;

"Normalization" of generalized malpractice that was considered inappropriate and illegitimate before the "destruction of society", such as using public transportation without a valid ticket, using things which are someone else's property, doing things that are considered good from the perspective of self-interest, disregarding the rights and benefits of others, destroying the lives of others, including taking someone's life if it is in one's own self-interest.

Mass forgetting of ethics and morality (not, primarily, a "confusion of values"), which generates tacit, collective tolerance of inhumane doings, including killing innocent individuals, destroying houses, homes, the foundations of human existence of those who are not "on our side", forced massive emigration, "cleansing" of territories, and similar wrongdoing;

Massive impoverishment, even of those members of society who would usually not be considered "poor", but whose real quality of life has been so degraded in comparison to their previous living conditions that they consider their personal situation to be a state of de-civilization, as a regression to a lower standard of living. They leave behind, even forgot their former lives.

This analytical description of a "destroyed society" might be considered incomplete or unacceptable in all of the above-mentioned dimensions. Evidently, it is very difficult to make such a complex concept "operational" to meet the demands of a specific empirical investigation into the manifestations of the "destruction of society". Respecting the limitations of the above-described concept of destroyed society, the following pages deal with some relevant findings which emerge from a detailed study of the "destruction of society" in Serbia in the 1990s and afterwards. This author believes that, even if they are not sufficient in all respects, these findings support the sociological assessment of society of Serbia in the past two decades (1990-2012) as destroyed; as a society which will have to go through a process of reconstitution - a more complex and a more difficult process than the process of "transition" and "post-socialist transformation" that other "post-communist" countries in East-Central Europe had to face. 


\section{DESTRUCTION OF SOCIAL STRUCTURE OF SERBIA}

All available findings lead to the conclusion that, from the beginning of the 1990s, Serbian society did not have a well-formed social structure. On the social scene there remained at the same time greatly deconstructed parts of former social groupings (fragmented and socially degraded "working strata", de-stratified peasants, a greatly de-structured middle strata, still relatively powerful fractions of the former "functionary class" or political bureaucracy), and a poorly-constituted new owner stratum (relatively numerous small entrepreneurs, a segment of peasantry who had been successful at commercializing production, owners of larger privatized former state enterprises, owners and managers of foreign firms located in Serbia). Considering this de facto "de-structured structure", it seems improper to denote Serbian society during the 1990 s as being a society with a system of restored capitalism, whose developmental "logic" would be generated by the newly re-established capitalist identity of Serbian society since the beginning of the 1990s. M. Lazić (2011) describes Serbian society since the 1990s as a society with a "blocked transition" from socialism to capitalism, and not as a case of clear "restoration of capitalism".

An indicator of the situation of a "destroyed" Serbian society which reflects a social structure faced with the process of "de-structuring", is its inability to create "great social coalitions" capable of comprehensive social action, as well as the impossibility of achieving a level of social consensus which is a necessary prerequisite for the articulation of a strategy of longterm, successful "systemic" social action. One can also stress the inability of the key "structural actors" to establish "social hegemony", as described by A. Gramsci (1971).

Since the end of the year 2000 in the Serbian political arena there have been so-called "impossible coalitions" (coalitions of former "Socialist" and political forces that were members of the so-called Democratic opposition of Serbia (DOS), coalitions of new social-democrats and advocates of neoliberal capitalism, coalitions of those in favor of the restoration of the monarchy and those advocating that Serbia be a constitutional "republic", etc.). Of course, there are differences in the political programs of the parties who join these "impossible" coalitions, but these variations do not generate major conflicts of interest during the articulation of specific policies of societal governance. It seems that pre-existing political conflicts are greatly about taking control of the sources of state power, or are even created by the personal ambitions of members of the government. From the point of view of "ordinary" citizens, those "in power" have been prevalently greedy "selfish guys" who have used 
power mainly for their own benefit. The selfishness of those in power in a destroyed society tends to be basically amoral, but presented in public as legitimate from some ideological (patriotic, religious, ethnically motivated) standpoint.

The de-structuring of actual Serbian social structure is also reflected in the real fragmentation and practical lack of legitimacy of the social elite. There were awkward public perceptions and characterizations of the elite in Serbia during the 1990s and even after the regime change in fall of the year 2000. In its basic conception, the "elite" has positive connotations, denoting those who are "elected" as the "best" or "excellent". Of course, to be a member of the "elite" has involved having some benefits that "ordinary" members of society cannot have, like outstanding respect, recognition, great social power and more favorable chances in life, including some legitimate privileges. It is relevant to stress that the positive connotations associated with elite status assume that reaching the "apex" of the social pyramid cannot be achieved "overnight", cannot happen without a demonstration of personal qualities, and should not involve moral or any other behavioral "stains" in the climb to "elite" status in the given society.

Of course, in social reality, especially during the period of the "building of socialism" in Serbia, meritocratic principles were of variable relevance. In the years immediately after 1945 , most of those in the elite stratum were respected for their positive roles in the battles for the liberation of the country from the Nazi occupation, for the elite's contribution to the renewal of the destroyed country. The very climbing to the elite positions itself was in most cases gradual, was related to the successful fulfillment of public duties and was connected with impeccable individual personal morality. In subsequent years, following the "stabilization of socialism" many of the previouslyrespected Party and State leaders become increasingly greedy and ignorant about the real interests of working people. Inclusion in the "nomenclature" meant assuming loyalty to the "first leader" of the Party.

In Serbian society, during the 1990s and afterwards, the "elites" were perceived by the public to be "social groupings" of variable composition and domains of activities. In the consciousness of most people, "elitism" lost its positive meaning. Even if not in every case, many of those "elite" were seen to be individuals who proclaimed themselves, or were proclaimed by some narrow clique, to be members of the "elite". Quite frequently, they were and still are individuals with moral and other "stains" in their biographies, lacking many positive traits. The pronounced illegitimacy of great segments of the "new elite" affects negatively every successful individual whose success is also questioned. Consequently, this makes people" "turn their back" on all 
"structures of power" and leads to the withdrawal of public support for all even positive - constructive leading forces in contemporary Serbian society. Even though there are a lot of new people who have assumed political roles, and despite many new governmental measures, social crises remain the enduring feature of "destroyed" Serbian society in the 21st century.

\section{THE DEFICIENCIES IN THE SOCIAL SYSTEM IN SERBIA SINCE THE 1990s}

From the beginning of the 1990s, there were many changes in the Serbian social system. In Serbia, as well as in other former "socialist" countries, reforms aimed at replacing the former "socialist" system with a new "postsocialist" social system (for some actors in those changes, the change had to be the restoration of a capitalist social system). Such fundamental social changes normally bring problems and difficulties to the society undergoing change. Some degree of "non-systemic" functioning of a given society seems to be unavoidable. Such features of the insufficient and inconsistent "systemic" regulation of a given society could be considered the normal price of transition, and not necessarily a sign of societal destruction. However, in Serbia in the 1990s and afterwards, besides the "normal" social difficulties caused by the replacement of the former "socialist" social system with a new "post-socialist" order, there were many fewer "normal" social developments. As first, there were numerous non-institutional activities, which were not of short duration. These non-institutional "doings" were observable in all societal domains. Specifically, socio-systemic changes in ownership relations, of the governance regime, and of the constitution of the central state government remained institutionally unfinished. In social reality, therefore, greatly incompatible social arrangements came into existence. From the 1990s onwards, many of the former "self-managed work organizations" remained nominally in "social ownership" for years because they were neither privatized nor transformed into "state enterprises". However, these organizations could not undertake the self-management of their' employees (Molnar, 1996), nor could they appoint self-managing "bodies". The management role was given to acting directors appointed by local authorities, but their management decisions were not controlled by employees in the firm or by any other institutionally-mandated body.

Contrary to the expected weakening of the role of the state, and a generally reduced influence for politics on the economy in Serbia (expected as a consequence of the post-socialist transformation), during the past two 
decades there has been a de facto predominance of state governance and "political factors" have played a crucial influence on all spheres of social life. This feature of "system inconsistence" must have had negative effects on all social developments. This is both an indication and a cause of the societal destruction of Serbia in this period.

The "systemic" formation of a society as a normally institutionallyarranged human community requires, besides other features, basically "congruent" social rules that are applied in various subsystems such as the economy, polity, culture and the spiritual sphere. It is assumed that the desired behaviors in one of the domains will be supported by practices in other spheres of social life. In Serbia during the 1990s and afterwards, due to the intentions of new social actors, some changes in the global value system were enacted, specifically in the new value placed on individualism (in contrast to the former "socialist collectivism"). This new "value paradigm" should have been supportive of the restoration of capitalist social relations, leading to the more efficient economic and overall social development of Serbia. However, due to the peculiar "ethno-nationalization of society" (Bolčić, 2013: 114-120), in an attempt to constitute Serbia as the Serbian state and society in an ethnic sense, in social reality, particularly in the sphere of politics and culture, "traditional collectivism" as a value orientation became of great importance, with an emphasis on serving the collective interests of the leading and constitutive (Serbian) nation, with the expectation that there would be a return to traditional patterns of collective life in the family, in local communities, and even in society in its totality. These "incongruent" value orientations had a negative impact on the overall social integration of Serbian society in that period.

Incongruent value orientations also existed in the domain of culture. On the one hand, people were expected to embrace patterns of behavior characteristic of developed "Western" societies; specifically, to follow fashion trends from the "West", at least in their appearance in the public sphere. At the same time, they had to manifest their belonging to their "Serbian nation", to demonstrate their respect for revived national mores, to show symbols of their belonging to the Serbian Orthodox church, etc. This attempt to behave simultaneously in accordance with "modern-time rules" and also in accordance with revived traditional Serbian values often had some grotesque results; e.g. when certain men with hair-cuts typical of "Rambo warriors" started wearing wooden cross necklaces typical of orthodox monks. Or, when women in short skirts and shirts, showing lots of flesh (typical of young "call-girls"), started wearing big golden crosses, normally worn by ladies with shirts buttoned up to their necks, when going to church. These are just illustrations of the prevailing 
"non-cultural culture" which became one of the manifestations of the overall destruction of society of Serbia in the last two decades.

\section{ON THE DESTRUCTION OF SOCIAL INSTITUTIONS}

Every specific social institution has its peculiar functional domain and specific institutional functions. By their form, institutions can continue to exist even after they have lost their original functions. In such a case, people can treat these institutions as "habitual frames" which require some ritual behavior, or they can consider them to be senseless, "emptied social forms". Institutions change through the introduction of new social rules under the influence of new social actors who emerge to control these institutions (for more on institutions and institutional change see Brinton and Nee, 1998). Some of these changes were so radical that they signified the formation of new institutions. During the processes of institutional change, one could expect some inconsistencies with institutional rules and the malfunctioning of such institutions. Such situations can be perceived by people as being situations of "social disorder". Still, if such an episode of "institutional confusion" is short-lived, and basic social regulation is being provided for within and by appropriate institutions, global society may still be considered an ordered social "entity" where social developments are largely predictable.

Fundamental destructive social change begins when institutions cease to fulfill their basic social function, when they become permanent "empty forms" and when the regulation of society occurs through various non-institutional forms, by some "quasi" or "para" institutions. "Quasi" or "para" institutions become visible in social reality under "names" similar to regular institutions, like "Coordinative body", or "Serbian guard". These "para-institutions" make "decisions" which regulate the behavior of people in the given domains such as in recruiting individuals for combat and other activities, such as collecting money to "help" people, etc. Some of the leading persons in such "parainstitutions" may have roles in official institutions but these official institutions have not given formal authority to such individuals to take part in such "quasi" institutions. The "otherness" of these 'para' institutions, in comparison with normal institutions, is that they function according to "unknown rules", through questionable legitimacy, using rules which protect some particular, illegitimate interests. The social power of actors that control these 'para'-institutions is mostly lacking. Therefore, the overall destruction of social institutions occurs when the social power of certain actors becomes uncontrollable and when social "regulation" favors particular "private interests". 
The destruction of the institutions of state is of crucial importance in the overall destruction of society. In Serbia, a specific "irregularity" in the functioning of the institutions of the state began before the dissolution of the Yugoslav federal state. Through the Constitution of Serbia, enacted in September 1990, the Republic of Serbia defined itself as an independent state, not explicitly as a "federal unit" of the Socialist Federal Republic of Yugoslavia (Pajvančić, 2005:20). From a legal perspective, this was a deviation in the normal functioning of the institutions of the state of Serbia. From that moment on there were many other social developments that lead to the gradual destruction of the institutions of state in Serbia, when many crucial state decisions were made by actors who were acting outside the regular institutions of the state. The de facto involvement of Serbia in "internal wars" (those in Croatia, Bosnia and Herzegovina, Kosovo) assumed the compliance of the Assembly of the Republic of Serbia. In fact, there was no such concordance, and those de facto making such decisions acted outside regular state institutions.

Since Serbia was involved in the "internal wars" within the borders of the former state of Yugoslavia, it should have been expected that the stillexisting institutions of the state in Serbia would enter a process of abnormal functioning, with the marginalization of the legislature and increased power for the executive. Since Serbia, as a state, was in a peculiar "state of war", the increased stress on the repressive functions of the state were predictable. According to some findings, the police force of the Serbian state had increased from 25000 at the beginning of the 1990s to almost 100000 at the end of the 1990s. However, typical state decisions about the mobilization of military reserve forces and of the deployment of police and army units which were sent, informally and unofficially to "war zones" in Croatia and Bosnia and Herzegovina, and many other decisions relevant to war activities, were made and enacted "extra-institutionally", disregarding institutionally-defined procedures. Nominally, The President of Yugoslavia (Slobodan Milosevic) and an institutionally non-existent "Coordination body" (whose members were key politicians of Serbia, selected most probably by S. Milosevic) were making and enacting strategic and operative decisions for the Serbian state, claiming that such decisions, under the existing conditions, were needed to safeguard the vital "national interests" of the Serbian nation, dispersed throughout the former republics of Yugoslavia. Some non-state actors such as "citizens" associations" made up of individuals willing to "volunteer" in protecting the life and "national interests" of the Serbs living in any part of the former Yugoslavia were also involved in "defense activities". Such associations had even their "para-military" units which were "sent into 
defense actions" in "coordination" with the authorized state organs, but often following the independent decisions of the "leading organs" of such associations. Evidently, such "extra-institutional" activities contributed to the degradation of regular state institutions and, consequently, to the destruction of the institutions of the Serbian state. One can claim that in such a social context a group of nominal state functionaries became private possessors of the state and made state decisions "in the name" of Serbian citizens. N. Dimitrijević (2004: 58-59) states that in Serbia during the 1990s there existed "a system of privatized governance". The consequences of such decisions were generally tragic for the citizens of Serbia, for people in other parts of former Yugoslavia, and, in the long-run, for the future of the Serbian state and society.

During the times of destruction of state institutions, a widespread disrespect for law and all other legal rules becomes "normal", first through disrespect for those with state power, but then through general disrespect for the "ordinary" citizens of such a state. As confirmed by survey findings (Bolčić, 2013:151) carried out during the years of the "destruction of society" in Serbia, the majority of people in Serbia agreed that the laws that existed in the 1990s were less well respected than before the 1990s. Two thirds of respondents considered this disrespect for law to be a precondition of survival, and as legitimate if it proved crucial for safeguarding someone's interests. Such findings warn that under peculiar "irregular" socio-structural conditions, like widespread pauperization and the lack of provision of basic goods for living, most individuals in such a "destroyed society" tend to become "offenders". Although undesired, even "ordinary" citizens can this way contribute to the "destruction of society", which is not in their fundamental interest.

The normalcy of any society greatly depends on its normality in terms of the functioning of its economic institutions, whose social function is to mobilize and activate disposable economic resources, to ensure the production and exchange of goods and services needed to ensure a civilized way of life for people in a given society. Economic institutions tend to exist and function even when there are major social "disturbances" in other spheres of society, particularly in politics. It is known, for example, that during wars between states, most enterprises continue to function (Milward, 1977).

In Serbia during the 1990s there were some "expected" disorders in the functioning of economic institutions, partly caused by changes in the economic system by the transformation of ownership relations. Some general malfunctioning of the Serbian economy also resulted from the economic sanctions imposed by the UN and other international bodies, provoked by the involvement of Serbia in the "Yugoslav wars". Considering these 
circumstances, one should say that the disturbance in the functioning of economic institutions in Serbia was accentuated due to the overall destruction of Serbian society. It should be mentioned that, in Serbia during the 1990s, there were numerous work organizations, enterprises, shops, etc., which could only nominally be denoted as "places of business", where people actually worked and had some function. People were "employed" in factories which had no production; they went to retail shops which had no goods to sell. Banks ceased to be "financial institutions" as they could not provide financial services for their business partners, nor could they make it possible for depositors to save and withdraw their money when they needed it.

At the time when regular economic institutions were ceasing to fulfill their normal institutional functions, a "mushrooming" of "para" firms doing "extrainstitutional" business in the "grey market" occurred (goods were offered for sale on the street, on car hoods; street "dealers" provided "financial services" by exchanging foreign currencies, lending money, offering to informal depositors some interest on their "deposits" and basic financial transactions were conducted not in the official currency - the dinar - but in the German mark). Due to such severe destruction of economic institutions (Dinkić, 1995), the state lost its capacity to use normal state measures in order to regulate economic life in Serbia. This resulted in a widespread scarcity of various, even basic, provisions. Such goods could most often be found in the "grey market" where prices could not be controlled by the state; as a result, prices sometimes increased several times during the day. This was one of the causes of galloping inflation and of the devaluation of the purchasing power of the official currency. State institutions even became "participants" in the nonlegal provision of various goods (e.g. gasoline, "strategic goods" needed by state institutions, etc.) Due to international economic sanctions, such goods as were needed for "state purposes" had to be supplied by unofficial suppliers (i.e. privately owned firms). These "services" provided by private firms to the state were often generously paid for, sometimes "in kind", and through non-disclosed "favors", creating a structural base for all kinds of corrupted relationships between private suppliers and state officials. The provenance of the "first millions" (in those years, expressed in German marks) of many big businessmen was not later described, for they were not pressed to explain how they had accumulated such sums, although it appears that the money was made during those years of the social destruction of Serbia. It seems selfevident that a society where corruption affects all the key social activities in such a fundamental way cannot be anything other than a destroyed society in the substantive meaning. 
Galloping inflation was perhaps the most disturbing sign of the overall destruction of society in Serbia during the 1990s. While in 1989 prices grew by $195 \%$, in the year 1992 prices were growing at an annual $9000 \%$. By the end of 1993 and at the beginning of 1994 the rate of inflation had to be calculated on a daily basis: in January 1994 inflation was 60\% daily, even 2\% per hour (Dinkić, 1995:43).

Considering all these facts, it was inevitable that Serbian society would become a profoundly pauperized society. According to the official statistical findings, $14 \%$ of all people were poor in $1990,39 \%$ in 1994 , and $33 \%$ in 1999 (Pošarac, 1995). In a survey study (Bolčić, 2002) conducted in the year 2000 , only $1 \%$ of respondents reported that their living standard was "good", while $78 \%$ answered that their situations in life were "hardly bearable", or "unbearable".

Processes of the destruction of institutions were visible even in the functioning of religious institutions. The 1990s were certainly the years of the revival of religiosity and the uptake of overtly-religious behavior, especially in relation to the baptizing of children, marriage, burial ceremonies, the celebration of religious holidays, as well as in the display of one's religious orientation through wearing crosses and the display of religious objects such as icons, etc., in one's home (see findings, Radisavljević-Ćiparizović, 2002). The 1990s were also years of increasing influence for churches as institutions and church dignitaries became more visible in wider public life, including political life, in Serbia. Considering such facts, it would seem inappropriate to claim that there was a trend towards the destruction of religious institutions. However, if one has in mind the original and specific functions of religious institutions; i.e. strengthening the spiritual orientation of people and their religious beliefs $s^{3}$, then the actual "doings" of religious institutions cannot be said to be in accordance with their specific institutional functions. "The word of the church" was often heard in relation to non-church and non-religious matters, about the state and political activities, and was not heard in relation to the condemnation of various inhumane, nonChristian activities (such as torturing or killing people, taking other people's property, amoral behavior in various situations, including the amoral behavior of the "people of the church"). While men of the church expressed discontent with the general spiritual situation in Serbian society, asking for greater social influence for religious institutions, they often overlooked their contributions and their malpractice, as opposed to working to establish a desirable, proper spiritual situation in Serbian society.

3 According to findings presented by D. Radisavljević-Ćiparizović (2002: 123-131), only 2\% of the population surveyed regularly attended liturgy in their churches. 
In elaborating the features of destruction of Serbian society during the past two decades, one needs to underline some developments related to interpersonal relations in this society and to the peculiarities of the modal type of personality that prevailed in Serbia in that period. In sensing the destruction of society, people often felt society vanishing behind their back. They also lost their friends and others close to them. They were aware that it was hard to find those who would help and support them in their everyday lives. A survey (Milić, 2002:262) carried out in 1999 showed that $46 \%$ of respondents had fewer friends than before 1990. In some cases this loss of friends was affected by the massive emigration of people during this period (Bolčić, 2013:231).

In explaining these undesired changes in interpersonal relations and the shaping of a "modal personality" (for more on this, see Golubović, 1995: 8-9) it is important to underline the socio-structural circumstances generated by the process of destruction of society that entailed" such changes. It becomes normal that an individual "thinks most of himself" in most everyday situations and looks for personal gain even when this means overlooking the needs and rights of others. In the above-mentioned survey study, $65 \%$ of all respondents admitted that they "thought mostly of themselves" in those years, while $57 \%$ of the respondents agreed with the statement that in those years people were "less honest" than in the pre-1990 period. This disregard for morality was one of the manifestations of a destroyed society and may highlight the reason why people all over the former Yugoslavia were "inactive" in condemning the unquestionably inhumane doings of many individuals that took part in war activities in the area, and who did not express their disapproval about forms of criminal activities that made the lives of the majority of citizens of Serbia miserable.

In a society, where, by necessity, there is widespread disregard for moral rules, where there is considerable tolerance for amorality, one should expect weak motivation for civil action and a lack of all those activities in which autonomous persons, moved by their consciences, attempt to improve the overall quality of life of other members of society. According to some findings (Bolčić, 1999), this peculiar mode of destruction of civil society has also been a manifestation of the general destruction of society during the 1990s.

The hitherto-presented findings concerning the social situation in Serbia during the 1990s should be treated as just the first illustration of the manifest destruction of Serbian society. 


\section{ON THE CAUSES OF THE DESTRUCTION OF SOCIETY}

The starting point for this study is that the processes of the destruction of a society generate very profound, long-lasting disorders in the functioning of a given society. The destruction of Serbian society at its root continued after the regime changes in Serbia in October 2000, in spite of significant attempts to stop those sinister social developments. Even if one makes a more systematic analysis of social developments in Serbia after the end of 1990, there are numerous indications which suggest that, since the year 2000, manifestations of the destruction of society have continued to be an essential component of Serbian social reality. Those who took leading roles in Serbian society after the dethronement of Milošević in the fall of 2000 were quick to admit that they were not aware of how profoundly destroyed all the social institutions in Serbia were. They had to learn painfully that neither their enthusiasm nor their expertise were sufficient to create prompt and substantive social changes in Serbian society, which continued to be heavily influenced by the negative consequences of social developments in the 1990s.

Among the circumstances that contributed to the destruction of society one should primarily pinpoint "war developments", especially the case of "internal war". One can learn from various historical precedents that societies facing "civil" or "internal wars" experience the most fierce confrontations, greatest destruction and atrocities, and even periods of de-civilization of longer duration. Therefore, in the search for circumstances that might have caused the process of the destruction of Serbian society, one should consider war on the territory of the former Yugoslavia, with Serbia being part of that country. Even if neither the state nor the society of Serbia had declared war on any other part of Yugoslavia, it is undeniable that both the state and the society of Serbia were deeply involved in the development of fighting in the "area of Yugoslavia". Those war confrontations have most often been defined as "civil", "interethnic" or even "inter-religious" war(s). If one considers the various "sides" involved in war activities, they cannot simply be defined as ethnicities, for in some cases the battle grounds witnessed even regular military formations of the newly-independent states constituted within the borders of former republics of Yugoslavia. Thus it seems more appropriate to qualify those wars within the borders of the former Yugoslavia as internal wars.

Involvements in such "internal wars" provoked deep disorder in the functioning of all the social institutions in Serbia, primarily in the functioning of the institutions of state. These institutions, influenced by changing situations in war zones, and even more by the way institutions were used by leading functionaries of the state, ceased to be institutions under proper 
institutionally-defined social control. Afterwards, these institutions were either marginalized (this being the case of legislative and judicial institutions), or put under the peculiar "private control" of the highest-ranking state official and his unofficially appointed "collaborators" who presumed that they had an unlimited "mandate" from the Serbian nation to use state means to secure and promote the interests of the Serbian nation. So, the destruction of society is an outcome of the involvement of a given society in an "internal war", and also of a peculiar "privatization" of state institutions.

The institutionally irregular "dissolution" of the SFR Yugoslavia contributed greatly to various disorder in the functioning of the newlyconstituted "republic-states" and also in the newly-constituted "republicsocieties". These newly-established "independent" states promptly underwent a new "constituting" and redefining of the state's social identity. Since the "ethnic problem" was perceived by most of the "new forces" as the crucial unresolved problem of the former Yugoslavia, the post-Yugoslav states and societies were re-constituted as ethnic states, as the states of the dominant ethnicity within the borders of the former Yugoslav republics. It seems just to conclude that such an "ethno-national" constitution for the new postYugoslav societies led to numerous inter-state conflicts, to hostile relations, including war. One should know that the former republics of Yugoslavia were not ethno-nationally homogeneous: $91 \%$ of the citizens of the Republic of Slovenia declared themselves to be Slovene; other republics contained up to $30-40 \%$ citizens of an ethnicity other than the dominant one in that republic. With the dissolution of Yugoslavia, the Serbs became the most numerous ethnicity (totaling 2 million) "left out" of "their ethnic state" (i.e. Serbia). It is important to stress that, at least in relation to the constitutional intention, the former Yugoslav republics were not ethno-nationally constituted social entities. According to the Constitution of SFR Yugoslavia, Serbs, Croats, Slovenes, Macedonians, Montenegrins, and Bosnians had the status of "constitutive nations" in Yugoslavia and in all former Yugoslav republics. Because of the "ethno-national" constitution of the new post-Yugoslav states, considerable segments of those "constitutive nations" lost that status, becoming "ethnic minorities", which most of them could not accept, either as individual citizens, or as a collectivity of a given former "constitutive nation". The consequence of such sentiments made the new post-Yugoslav states states with limited legitimacy whose considerable number of citizens rejected, at least consciously if not actively, their loyalty to such a state. These citizens felt deprived of some of their former rights; they felt they were second-rate citizens, disbelieving that the good will of such an "ethnically biased state" would lead to them being treated equally, and fearing that their civil and 
human rights would not be secured - particularly fearing unfair treatment related to their "ethnic needs".

It should be expected that a society, lacking a consensus around the basic constitution of its state, will become a society of deep cleavages and tensions. This generates inefficiency and the speedy "ruining" of all social institutions. Therefore, the inter-ethnic conflicts were just one side of this "ethno-national" constitution of the new post-Yugoslav states and societies. There were also severe and destructive social developments that affected the everyday lives of the people in those territories. These were more severe in those "ethnic states" which were multiethnic to a greater extent. The ethno-national constitution of the new post-Yugoslav states generated the "ethno-national" formation of new societies in this region, expressed in the tendency to treat society as property of the dominant "ethno-nation" (Bolčić, 1995). This meant establishing a basic identity for a given society, its social order and its socio-systemic goals in direct service to the dominant ethno-nation. An "ethno-nationalistic" society is socially structured along ethnic lines, making all other divisions in society of a secondary importance. Not only state governance but also power relations in social terms have to be in accordance with the socio-systemic realization of interests of the dominant ethno-nation. All other components of the social, economic, political, cultural and spiritual spheres of a given society should be formed along these "ethnic lines".

Radical deviation from respect for basic human values, due to the pronounced socio-systemic biased treatment of any activities considered favorable for the leading ethno-nation, resulted in a peculiar disregard for morality, followed by an en masse breaking of legal rules, by the widespread criminalization of society, by frequent inhumane actions directed not only at individuals who belonged to ethnic group(s) with which the given society had hostile relations, but also to those individuals of the same ethnicity who were considered to be disloyal toward their ethnicity. If one takes into consideration the real multi-ethnicity of the new post-Yugoslav societies and the destructive consequences of the "ethno-national" constitutions of such societies, it is inevitable to conclude that just this process of "ethno-nationalization" of all post-Yugoslav societies, and Serbian society in particular, contributed in a fundamental sense to the destruction of society in the area of former Yugoslavia.

When analyzing the social circumstances that could have contributed to the process of destruction of society, one should not forget the long-lasting economic crises both in the former Yugoslavia and in Serbia as well. These caused widespread pauperization of the inhabitants of this country. It is important to stress that "pauperization" in this case did not solely occur 
to individuals with very low incomes, already struggling to meet basic existential needs, but to masses of former citizens who had respectable living standards and who "overnight" had to radically reduce their living standards and to go through a process of 'de-civilization'. Individuals, in some cases unemployed and unpaid during the 1990s for years, lacked basic existential means and resorted to being selfish and "forgetting about their society" as they looked for ways to solve their problems, along the way disrespecting regular institutions and disrespecting legal rules. A massively pauperized society cannot be a well-ordered society in which institutions and individuals act in accordance with their social roles. Therefore, under the given sociostructural conditions, even "ordinary" citizens can contribute, through their activities, to the destruction of society. Of course, their impact on this process is not autonomous. More relevant are the activities of powerful social actors who decisively contribute to the formation, functioning and destruction of social institutions and to the functioning of the social system in its totality.

In the preceding analysis of the social circumstances which could have precipitated the processes of social destruction several circumstances were mentioned, but none of them can be characterized as "decisive". In the case of Serbia during the 1990s, the destruction of society was most probably a result of the simultaneous impact of a "multitude of factors". Of course, some of those circumstances preceded other circumstances: i.e. the long-lasting social and economic crises in Yugoslavia were severe and destructive since the beginning of the 1980s. "Economic instability" seems to have been the crucial reason for the widespread popular dissatisfaction in Yugoslavia during the 1980s; this was qualified as "economic instability" by the leading political and state organs of Yugoslavia. At the beginning of 1982, the Presidency of Yugoslavia appointed the Commission for the long-term program of economic stabilization, presided over by the President of The Presidency (Sergej Krajger). A group of leading sociologists, coordinated by the current author, was asked to prepare a document about the "social aspects of the program of economic stabilization". In that document, the sociologists characterized the social situation in Yugoslavia as a situation of social crisis, not just as a situation of "economic instability", proposing radical socio-systemic changes as a way to overcome even the problems with economic instability. At the time this assessment from the sociologists was not accepted by the leading politicians in Yugoslavia, including the politicians in Serbia, although there was no direct opposition to it (the statements of the sociologists are reported in Scientia Yugoslavica, No. 4-5, 1985, Zagreb).

Discussions about the necessary measures for economic stabilization opened up a confrontation between the "leading figures" of various republics, 
expressed mainly as a dispute about relations in the Federation. Leaders of some republics, specifically those in Slovenia and Croatia, blamed federal institutions for enacting inappropriate economic policy measures, for creating inappropriate investment policy and poorly regulating the economic contributions of republics to the Federal funds (that were mainly distributed to the less-developed parts of Yugoslavia). Some leaders (in Serbia and also some less-developed republics) advocated a "stronger Federation"; others were in favor of greater independence in the activities of the state organs in the republics: i.e. of a "weaker Federation" or "asymmetrical" Federation. Although the republics of the former Yugoslavia were not constituted as "ethno-national states" but as "socio-political communities" of all the citizens living in the territories populated mostly by the citizens of a given ethnicity, the cleavages concerning the "relations in the Federation" were felt to be "nation-based" (ethnic) in Yugoslavia because of their conflicting "national interests". One could have predicted that this "ethnic" articulation of conflicts of representatives of the nations would provoke the rise of national sentiments of "ordinary" citizens, the rise of a massive sense of frustration from members of the given ethnicities, the revival of national ideologies and even some preparatory activities for safeguarding the vital interests of the "nations" if endangered by other "nations".

It must be stressed that in their discussions about the relations in the Federation, the politicians of the republics avoided qualifying their own positions, as well as the positions of others taking part in discussions, as "ethnically-biased", or favorable to the interests of a certain "constitutive nation". All positions that were made overt were expressed in terms of advocating further development of a "self-management" mode of governance in all segments of Yugoslav society and the making of efforts in favor of modernizing and democratizing Yugoslavia. It looks as if the media and the "creators of the public opinion" played a major independent role in the revival of national sentiments, evoking bad memories of previous ethnic clashes. Among "ordinary" citizens there remained the prevailing perception that, all in all, the inter-ethnic relations in each of the republics, and in Yugoslavia in general, were good (see Lazić, 1991). Even the problems and cleavages that were expressed were perceived as only being resolvable within the existing constitutive framework of Yugoslavia as a multi-ethnic state and a multi-ethnic society. Well, in spite of those prevailing feelings among "ordinary" citizens, most of whom did not foresee any threatening conflicts, real social developments took a different, tragic path towards "resolving" those conflicting "demands" for redesigning the Federation through war within the borders of the former republics and within the borders of the former Yugoslavia. 
Searching for an explanation for the tragic course that was taken to resolve the Yugoslav crisis of the 1980s, one has to consider the role of specific powerful social actors (bureaucracies in republics, leading military cadres, nationalistic segments of the cultural elite) who played an important role in the final characterization of the essence of the state and the social problems in Yugoslavia at the end of the 1980s, and who, in making strategic decisions, tried to resolve the problems. There is also another phenomenon that should be considered more fully. Namely, the long-lasting social crises, clearly manifested at the beginning of the 1980 s, that caused massive social discontent with a worsening of individual living standards, and even more, discontent with the crying inefficiency and incapacity of "politicians" to define measures that would resolve existing social and state problems. These contributed to the formation of a social atmosphere in which demands for quick, decisive solutions were accentuated. Such an atmosphere was fertile ground for the "demand" and also for the "supply" of political actors who had (or pretended to have) the necessary qualities and the ability to take prompt and decisive action to overcome disturbing social problems. Even if, from some superficial insight, one might come to the conclusion that some of the key contributors to the tragic developments in the given "destroyed society" somehow "self-elected" themselves to these leading positions, one should not forget the socio-structural context that enabled such individuals to assume the leading roles, and one must also be aware of a multitude of actors, visible and invisible, supporting the activities of these key historical figures. Emphasizing this "side of the story" should not mean undermining the fact of the real role and responsibility of some of the key political figures in starting and maintaining the processes of the overall destruction of the given society.

The role of personality must be considered in this attempt to understand the process of social destruction of Serbia during the 1990s. Even if significant investigation is needed in order to understand the essential social circumstances which lead to the destruction of the society in Serbia, it seems to be a reliablyestablished fact that Slobodan Milošević, in the role of the President of the Federal Republic of Yugoslavia, played an essential and sinister role in the initiation and "stabilization" of the processes of "destruction of society"; i.e. both of the multi-ethnic Yugoslav society and of newly-constituted Serbian society.

Without attempting to undertake a comprehensive analysis of S. Milošević's actions in regard to social developments in Serbia in the last two or three decades (since the 1980s), in the context of this analysis of the destruction of the Serbian society, particular attention will be given to his contribution to the processes of destruction of Serbian social institutions. It is relevant to know 
that some of his activities that contributed to the later destruction of social institutions in general started at the beginning of the 1980s; that is, before the final "dismantling" of Yugoslavia as a multi-ethnic federal state, and also before the beginning of war activities in the "Yugoslav area". One might say that, in a symbolic sense, "the Milošević era" was announced on the poster for the $10^{\text {th }}$ Congress of the League of Communists of Serbia (1986); the poster with a characteristic strong fist that was displayed when Milošević was elected President of the Central Committee of the Serbian Communist League. Soon after, he was "enthroned" as the most powerful politician in Serbia, S. Milošević undertook activities designed to "unravel" the social crises in Yugoslavia, as well as in Serbia (see, Milošević,1989; the title of the book in Serbian is Rasplitanje krize; in English, The Unraveling of Crises). Unfortunately, his contributions to the "unraveling" of the "Yugoslav crisis" led to the "dismantling" of the Socialist Federal Republic of Yugoslavia, to the final destruction of the state of Yugoslavia and to a series of sinister developments in all parts of Yugoslavia. The destruction of society of Serbia is one of the sinister results of S. Milošević's "unraveling" of social crises of the 1980s in Yugoslavia.

The new "style" of S. Milošević's political activities was characterized as determination, prompt action, firm unity (not only within the Party, but also in society), which had to be achieved even if meant disregarding usual institutional procedures. This new "style" was visibly demonstrated in the way S. Milošević performed his role of President of the Presidency of the Central Committee of the LCS (for more on this, see Pavlović, 1988:42, 45 and 63). What is relevant here is the conflict within the Presidency of the Central Committee between S. Milošević and D. Pavlović, President of the Party Committee of Belgrade, which ended with the ousting of D. Pavlović from all the "Party" bodies and from the "Party" itself. The mode of resolving this "intra-Party" conflict, also witnessed in Milošević's subsequent activities in "resolving" other social "situations" in Yugoslavia and Serbia, clearly indicated his disrespect for institutional arrangements. Also, this superficially-characterized "intra-Party" conflict demonstrated a new Serbian "ethno-national" policy, which inevitably led to the destruction of Yugoslavia as a multi-ethnic state and society.

S. Milošević was explicit in his advocacy of non-institutional methods of resolving social issues: "But the solution will not come through procedure, its small and big traps, small and big trickeries, intrigues and wiles. The solution will provide the policy chosen by the majority of people of this country, institutionally or non-institutionally, according to the statute or against the statute, on the street, or inside, in a populist or elitist way, with 
arguments, or without arguments; in any case it should be clear that this will be in accordance with the politics for Yugoslavia in which we will live in a more united way, we will be treated more equally, become wealthier and more cultured" (Milošević, 1989:333). The real effects of such a "policy" became more and more damaging in all domains of life in Yugoslavia and Serbia. Among those "deserving recognition" for the destruction of society one can hardly question the leading position of Slobodan Milošević.

\section{ON THE RECONSTITUTION OF SOCIETY SINCE OCTOBER 2000}

It has been mentioned that the processes of social destruction are complex processes of a longer duration, generated by many actors and factors. Therefore, it was unrealistic to expect the immediate reconstitution of society in Serbia after the dethronement of the "old government" and the electoral victory of anti-Milošević's forces in the autumn of 2000. Of course, there were some positive developments: positions in state institutions were mostly taken up by persons selected through free and fair democratic elections. The living standards of the majority of citizens slightly improved. The share of the "grey economy" decreased. In 1995, it was assessed (Krstić, 1998) that unregistered income in the grey economy accounted for some 50\% of GDP; in 2010, the grey economy was assessed at 30\% of GDP (Madžar, 2013). Most of the economic life since autumn 2000 has returned to the usual legal forms and institutions. Still, many of the above-mentioned features of a destroyed society have continued to exist in Serbian society since the year 2000. The activation of disposable domestic economic resources (both material and human resources) has been insufficient. Retail trade activities and financial transactions have been revived mostly owing to the liberalization of foreign investments and financial and trade activities. However, because of this "model" of economic revitalization there has been a great increase in the external debt, the undervaluation of the de facto domestic currency, and the number of unemployed has continued to rise.

In the political domain, in the socio-systemic building of the state and society, there are still many "unfinished" developments. Most of the issues concerning the state borders after the dissolution of the Yugoslav state are still open. From the socio-structural perspective, Serbian society continues to be very fragmented and has an elite whose legitimacy is still in question. Under such conditions, state institutions continue to inefficiently carry out their functions, especially in terms of making proper, socially-accepted strategic 
decisions. People continue to see that key political decisions are being taken outside of the appropriate institutions. In spite of some improvements in living conditions, most citizens subjectively perceive their situation to be similar to what they experienced in the 1990s. In terms of public reactions, one can continue to speak of a "moral" crisis, of widespread selfishness, of corruption, of low trust in institutions and of a need to "evade the legal rules" in securing one's essential personal interests. In such a social atmosphere social and individual perspectives are unclear. A great number of young people still see their future as somewhere abroad, and the "brain drain" trend that started in the 1990 s continues.

The transformative changes that have occurred since October 2000 have ensured a rapid turnover of personnel at the apex of the social pyramid, not a radical change in the strategic orientation of state and social building of Serbian society. There has been a break with the Milošević regime through the replacement of a greatly autocratic governance with a more democratic governance; through the formation of a more responsible executive branch of government; through the abandonment of the policy of confrontation with the rest of the world, by enhancing cooperation with the "international community", and by building less hostile relations with neighboring states; by substituting the dominant state-social ownership of the means of production mostly with privately-owned economic units, etc. However, even if all of the above-mentioned transformations had been successfully carried out, one would still have to say that such changes are "small transformations", not "great transformations", according to K.Polanyi's (Polanyi, 1944; see, also Lengyel-Rostoványi, 2001) interpretation. In the case of Serbia, one should recall that the basic "tone" of all political and social developments originated from "battles" for "national interests". Unless such "battles" are reconsidered, unless policy failures and those responsible for them are revealed, it is practically impossible to rebuild new societal strategies for the future of Serbia and to "leave behind" the sinister years of 'resolving' social crises; that is, the years of the destruction of Serbian society during the 1990s.

The new political forces in Serbia have tended to postpone the questioning of the "national agenda" of the 1990s, thus pushing themselves into an awkward and contradictory situation: on the one hand, these new political forces have established cooperative relations with the institutions of the "international community", including cooperating with the Hague tribunal, regaining, in return, the respect and credibility of those "foreign factors"; on the other hand, partly because of their cooperative approach toward the "international community" these new governing powers have lost the credibility and support of their citizens. Since a considerable number of Serbian citizens question its 
legitimacy and credibility, the new government was incapable of completely mobilizing all its disposable resources and of improving economic conditions in the country. It became clear that "ethno-national" issues would not be provisionally swept under the carpet for "tactical reasons". This kind of "social engineering", de facto, brings back the bad years of the 1990s; the discrepancy between the existing Constitution and the new social reality is maintained, contributing to the creation of inconsistent legal rules, which must be disrespected, thus leading to a situation of a destroyed society that is characterized by the negation of legal regulation as the key mode of keeping social order in modern societies.

Before the Serbian society achieves maturity in addressing the difficult issues of the "Serbian national program", a national program which is sufficiently different from the "program" that actors attempted to implement during the 1990s (but again, a program that will rebuild a sufficient consensus between the "masses" and their elites) is required to create a new "leap forward" and the reconstitution of society. Without this, Serbia faces a continuing blockade of its "post-socialist transformation", a limited scope of democratization and modernization, a loss of attractiveness to its own citizens; and even more, a reduction in its attractiveness to the rest of the modern world. 


\section{REFERENCES}

Bolčić, Silvano (1994), Tegobe prelaza u preduzetničko društvo (Hardship of Transition toward the Entrepreneurial Society), Beograd, Institut za sociološka istraživanja

Bolčić, Silvano (1995), The Features of a Nationalized Society, Sociologija, No.4, Beograd

Bolčić, Silvano (1999), Civic Performance in a Pauperized Society, in SkenderovićĆuk, ed., Civil Society in the Countries in Transition: Comparative Analysis and Practice, Subotica, Agency of Local Democracy

Bolčić, Silvano (2013), Razaranje i rekonstitucija društva: Srbija na prelazu u 21. vek (Destruction and Reconstitution of a Society: Serbia in Transition to the $21^{\text {st }}$ Century), Beograd, Službeni glasnik

Brinton, Mary C.-Nee, Victor (1998), The New Institutionalism in Sociology, Stanford, Stanford University Press

Diamond, Jared (2005), Collapse: How Societies Choose to Fail or Succeed, New York, Penguin Group

Dimitrijević, Nenad (2004), Srbija kao nedovršena država, in Vujadinović, D., ed. Između autoritarizma i demokratije: Civilno delovanje i politička kultura (Between Authoritarianism and Democracy: Civil Society and Political Culture), Beograd, Cedet

Dinkić, Mlađen (1995), Ekonomija destrukcije (Economy of Destruction), Beograd, Stubovi kulture

Golubović, Zagorka (1995), Društveni karakter $i$ društvene promene u svetlu nacionalnih sukoba, (Social Character and Social Change under National Conflicts), Beograd, Filip Višnjić

Gramsci, Antonio (1971) Selections from Prison Notebooks, London, New Left Books

Grupa autora (1985), Aktuelni trenutak jugoslovenskog društva i pravci dugoročnih društvenih promena, Scientia Yugoslavica, No. 3.4, Zagreb

Krstić, Gorana (1998), Uzroci i posledice sive ekonomije, in Milosavljević, M., ed. Socijalna politika $u$ tranziciji (Social Policy in Transition), Beograd, Centar za proučavanje alternativa

Lazić, Mladen (1991), Položaj naroda i međunacionalni odnosi u Hrvatskoj (Status of Ethnicities and Inter-ethnic Relations in Croatia), Zagreb, IDIS

Lazić, Mladen (2011), Čekajući kapitalizam: Nastanak novih klasnih odnosa u Srbiji (Waiting for Capitalism: Formation of the New Class Relations in Serbia), Beograd, Službeni glasnik

Lengyel, Gyorgy-Zsolt Rostoványi, eds. (2001), The Small Transformation: Society, Economy and Culture in Hungary and the New European Architecture, Budapest, Akademiai Kiado

Madžar, Lidija (2013), Siva ekonomija u Srbiji u svetlu tendencija u evropskim zemljama, Škola biznisa, No. 3-4

Milward, Alan S. (1977), War, Economy and Society 1939-1945, Berkeley, University of California Press

Milić, Andjelka (2002), Dobitnici i gubitnici u procesu tranzicije iz ugla porodične svakodnevice, in Bolčić, S., eds. Srbija krajem mileniuma:Razaranje društva, 
promene i svakodnevni život (Serbia at the End of Millennium: Destruction of Society, Changes and Everyday Life), Beograd, Institut za sociološka istraživanja Milošević, Slobodan (1989), Rasplitanje krize (The Unraveling of Crisis), Beograd, BIGZ

Molnar, Aleksandar (1996), The Collapse of Self-Management and the Rise of Fuerenprincip in Serbian Enterprises, Sociologija, No.4,

Pajvančić, Marijana (2005), Srbija između ustava i ustavnosti (Serbia Between Constitution and Constitutionalism), Beograd, Helsinski odbor za ljudska prava

Pavlović, Dragiša (1988), Olako obećana brzina (Easy Promised Speed), Zagreb, Globus

Polanyi, Karl (1944), The Great Transformation, New York, Rinehart an Co.

Pošarac, Aleksandra (1995), Pauperizacija stanovništva Srbije- jedan od uzroka potisnuti civilnog društva, in Pavlović, V., ed. Potisnuto civilno društvo (The Suppressed Civil society), Beograd, EcoCentar

Prošić-Dvornić, Mirjana, ed. (1994), Kultura u tranziciji (The Culture in Transition), Beograd, Plato

Radisavljević-Ćiparizović, Dragana (2002), Religija i svakodnevni život: vezanost ljudi za religiju i crkvu u Srbiji krajem devedesetih, in Bolčić, S.,eds, Srbija krajem mileniuma:razaranje društva,promene i svakodnevni život (Serbia at the End of Millennium: Destruction of society, Changes and Everyday Life), Beograd, Institut za sociološka istraživanja 